\title{
DETEKSI DINI PERILAKU PENYIMPANGAN SEKSUAL MENGGUNAKAN METODE FORWARD CHAINING BERBASIS WEB
}

\author{
Nur Rochmah Dyah P.A.1), Yoga Putra Pamungkas²) \\ ${ }^{1,2)}$ Program Studi Teknik Informatika Universitas Ahmad Dahlan, Yogyakarta, Indonesia \\ Email : rochmahdyah@tif.uad.ac.id ${ }^{1)}$, agoey.10@gmail.com²
}

\begin{abstract}
ABSTRAK
Perilaku penyimpangan seksual merupakan tingkah laku seksual yang tidak dapat diterima dikalangan masyarakat. Minimnya pengetahuan dan banyaknya kendala untuk mendapatkan informasi tentang pendeteksian secara dini dan mandiri masyarakat tentang penyimpangan seksual dan ketidaktahuan masyarakat dalam menyikapi penyimpangan seksual juga menjadi faktor tidak tertanganinya secara dini. Forward chaining, konsultasi dimulai dengan pencarian dari premis atau data masukan berupa gejala menuju pada konklusi yaitu kesimpulan jenis perilaku penyimpangan serta solusinya. Dari masalah diatas maka akan dibangun sistem yang berbasis Web yang berfungsi untuk mendeteksi awal secara mandiri tentang kelainan yang dirasakan yang dapat diakses dengan jangkuan yang luas dan waktu yang tidak terbatas.

Sistem dibangun menggunakan pemrograman PHP dan MySQL sebagai basis data. Metode yang digunakan untuk penulusuran adalah forward chaining. Sedangkan hasil diagnosa akan menginformasikan tentang hasil diagnosa berisi tentang daftar gejala yang dimasukkan, informasi hasil aturan tentang kelainan yang diderita dan informasi tentang kemungkian penanganan yang dapat diakukan.

Pengujian teknik black box ditekankan pada pemasukan data, hasil keluaran data, fungsi-fungsi dalam sistem, kinerja, dan inisialisasi dalam sistem. Sedangkan pengujian alpha test dilakukan dengan cara mengundang 10 responden pengujian ditekankan pada interface, dialog, dan informasi yang dihasilkan. Dari hasil pengujian alpha test menunjukkan bahwa sistem yang dibuat telah berjalan dengan baik dan menghasilkan informasi yang akurat, dan mudah difahami.
\end{abstract}

Kata Kunci: Deteksi Dini Penyimpangan Seksual, Forward Chaining, SI Berbasis Web.

\begin{abstract}
Behavior of sexual deviation is an unacceptable sexual behavior among the public. The lack of knowledge and the many obstacles to obtain information about early detection and community independence about sexual deviation and ignorance of the community in dealing with sexual deviation is also a factor not handled early. Forward chaining, consultation begins with a search of the premise or input data in the form of symptoms to the conclusion that is the conclusion of the type of deviation behavior as well as the solution. From the above problems will be built Web-based system that serves to detect the beginning independently of the perceived disorders that can be accessed with an extensive lap and time is not limited.

The system is built using PHP and MySQL programming as the database. The method used for forwarding is forward chaining. While the results of the diagnosis will inform about the diagnosis of the list of symptoms included, information on the results of the rules of the disorder suffered and information about the possibility of handling can be done.

Black box testing techniques are emphasized on data entry, output data, system functions, performance, and initialization in the system. While testing the alpha test is done by inviting 10 respondents testing is emphasized on the interface, dialogue, and information generated. From the results of testing the alpha test shows that the system created has been running well and produce information that is accurate, and easy to understand.
\end{abstract}

Keywords: Early Detection of Sexual Deviation, Forward Chaining, Web Based Infromation System.

\section{Pendahuluan}

$\mathrm{M}$ asalah penyimpangan seksual telah menjadi problematika sosial di kalangan masyarakat. Beberapa bentuk penyimpangan seksual antara lain perkembangan seksual yang berimbas pada gangguan identitas jenis, Parafilia, Disfungsi Psikoseksual dan masih banyak lagi. Dan sering kali penyimpanganpenyimpangan perilaku seksual muncul di kalangan remaja .

Penyimpangan seksual (sexual deviation) sering disebut juga dengan abnormalitas seksual (sexual abnormality), ketidak wajaran seksual (sexual perversion), dan kejahatan seksual (sexual harassment)[1]. Dikalangan masyarakat perilaku penyimpangan seksual merupakan tingkah laku seksual yang tidak dapat diterima dan tidak sesuai dengan tata cara serta norma-norma agama. Oleh karena itu tidak sedikit orang yang menderita kelainan seksual akan mengucilkan diri, merasa malu dan akan menyembungikan keadaaan dirinya.

Minimnya pengetahuan masyarakat tentang penyimpangan seksual dan ketidaktahuan masyarakat dalam menyikapi penyimpangan seksual juga menjadi faktor kurang maksimalnya penanganan dini terhadap perilaku penyimpangan. Akibatnya penderita penyimpangan tidak memiliki kesadaran penuh untuk melakukan pengobatan dengan psikolog tentang penyakit yang diderita. Bahkan terkadang seseorang tidak menyadari apakah mereka mengidap penyimpangan seksual atau tidak. Masih kurangnya kesadaran masyarakat untuk berkonsultasi langsung dengan psikolog dikarenakan perbincangan masalah seksualitas masih dianggap hal yang tabu dalam lingkungan masyarakat juga menjadi salah satu terhambatanya faktor penanganan dini. Di daerah keberadaan seorang psikiater masih jarang ditemui. Kebanyakan para psikiater berdomisili di daerah perkotaan serta di rumah sakit besar 
sehingga masyarakat mengalami banyak kendala untuk mendapatkan informasi tentang pendeteksian secara dini dan mandiri.

Forward chaining adalah strategi penarikan kesimpulan yang dimulai dari sejumlah fakta-fakta yang telah diketahui, untuk mendapatkan suatu fakta baru dengan memakai rule-rule yang memiliki premis yang cocok dengan fakta dan terus dilanjutkan sampai mendapatkan tujuan atau sampai tidak ada rule yang punya premis yang cocok atau sampai mendapatkan fakta [2]. Struktur rule secara logika menghubungkan satu atau lebih antecedents (disebut juga premis) dalam bagian IF, dan satu atau lebih consequents (disebut juga kesimpulan) dalam bagian THEN [2].

Dengan dibangunnya perangkat lunak sistem informasi untuk membantu pendeteksian dini perilaku penyimpangan seksual berbasis web yang bisa di akses secara real time (kapan saja), akan memberikan kemudahan konsultasi mandiri bagi semua masyarakat yang ingin mengetahui secara dini apakah dirinya mengidap penyimpangan atau tidak. Output sistem berupa hasil kesimpulan dengan metode forward chaining yang menginformasikan kemungkinan penyakit yang diderita dan kemungkinan penangan dari penyakit yang diderita.

\section{Metode}

Masalah yang terjadi adalah Minimnya pengetahuan masyarakat tentang penyimpangan seksual, minimnya kesadaran masyarakat atau penderita untuk berkonsultasi tentang penyimpangan, belum adanya sarana konsultasi secara mandiri sebagai penangan dini terhadap penyimpangan yang dirasakan penderita. Alur penyelesaian masalah sebagai berikut :

\section{A. Proses pelacakan dengan forward chaining}

Metode forward chaining adalah metode pencarian atau teknik pelacakan ke depan yang dimulai dengan Informasi yang ada dan penggabungan rule untuk menghasilkan suatu kesimpulan atau tujuan [3]. Forward chaining sering disebut runut maju, merupakan metode pencarian yang memulai proses memasukkan informasi atau fanta-fakta. Dari sekumpulan informasi atau fakta akan dikenai aturan-aturan yang kemudian dari aturanaturan tersebut diperoleh suatu kesimpulan. Runut maju memulai proses pencarian dengan infromasi atau fakta sehingga strategi ini disebut juga data-driven. Penalaran maju atau forward chaining merupakan suatu strategi pengambilan keputusan yang dimulai dari bagian sebelah kiri (IF lebih dahulu). Dengan kata lain, Proses penalaran dimulai dari fakta atau informasi yang dimasukkan untuk diuji dengan aturan-aturan yang sesuai untuk mendapatkan kebenaran hipotesa.

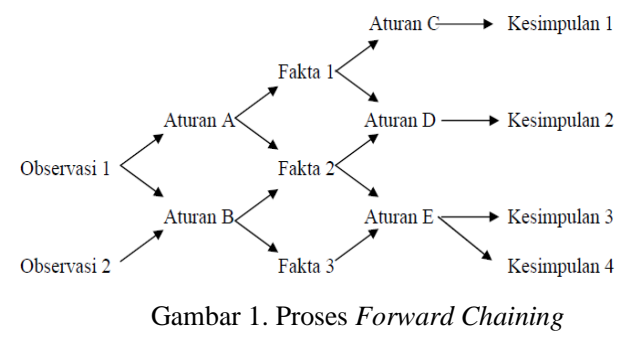

\section{B. Software Implementation}

Membuat aplikasi untuk membantu pendeteksian dini perilaku penyimpangan seksual berbasis web yang bisa dilakukan secara mandiri. Tahapan software development merupakan tahapan pembuatan sistem. Software development menggunakan Power Designer 6, Sublime Text, Ms. Visio, Photoshop, PHP, Boostrap. Proses testing menggunakan metode blackbox test serta alpha test.

\section{A. Analisis kebutuhan data}

\section{HASIL}

Berdasarkan hasil pengambilan data gejala yang sering timbul terdapat 57gejala. Data gejala terdapat pada Tabel I.

TABEL I.

TABEL Gejala

\begin{tabular}{cl}
\hline \hline KODE & \multicolumn{1}{c}{ NAMA GEJALA } \\
\hline G001 & Fantasi seksual kekerasan fisik \\
G002 & Seksual disertai tindak kekerasan fisik \\
G003 & Pasif dalam tindakan kekerasan seksual \\
G004 & Kepuasan seksual dengan disakiti pasangannya \\
G005 & Aktif dalam tindakan kekerasan seksual \\
G006 & Mengalami pengalaman traumatis dan pernah mendapatkan siksaan seksual fisik dan mental \\
G007 & Kepuasan seksual dengan menyakiti pasangannya \\
G008 & Keinginan untuk memperlihatkan organ seksual kepada orang lain \\
G009 & Dorongan yang kuat untuk memperlihatkan organ seksual \\
G010 & Tindakan untuk memperlihatkan organ seksual \\
G011 & Mendapatkan kepuasan seksual setelah memperlihatkan organ seksual \\
G012 & Pria akan merasa puas bila wanita terkejut saat melihat organ genitalnya \\
\hline \hline
\end{tabular}


TABEL I

TABEL GEJALA (LANJUTAN)

\begin{tabular}{|c|c|}
\hline$\overline{\mathrm{KOODE}}$ & "NAMA GEJALA \\
\hline G013 & Wanita akan merasa puas bila pria terangsang saat melihat payudara dan pantatnya \\
\hline G014 & Fantasi untuk melihat lawan jenis tanpa menggunakan pakaian \\
\hline G015 & Dorongan yang kuat untuk mengintip lawan jenis tanpa menggunakan pakaian \\
\hline G016 & Mengintip lawan jenis tanpa menggunakan pakaian \\
\hline G017 & Tidak berinteraksi secara seksual selain melihat sembunyi - sembunyi \\
\hline G018 & Mendapat kepuasan seksual dengan mengintip lawan jenis secara sembunyi - sembunyi \\
\hline G019 & Fantasi seksual terhadap anak dibawah umur \\
\hline G020 & Dorongan yang kuat untuk melakukan kontak seksual dengan anak dibawah umur \\
\hline G021 & Tindakan untuk melakukan kontak seksual dengan anak dibawah umur \\
\hline G022 & Fantasi seksual terhadap benda mati \\
\hline G023 & Ketertarikan yang berlebihan pada benda mati \\
\hline G024 & Memiliki koleksi benda mati yang membuatnya tertarik \\
\hline G025 & Benda yang umum digunakan $\mathrm{BH}$, celana dalam, kaus kaki dan lain - lain \\
\hline G026 & Tindakan untuk melakukan seksual terhadap benda mati \\
\hline G027 & Mendapatkan kepuasan seksual terhadap benda mati \\
\hline G028 & Fantasi seksual terhadap saudara dekat \\
\hline G029 & Dorongan yang kuat melakukan kontak seksual dengan saudara dekat \\
\hline G030 & Mencuri kesempatan agar bisa melakukan kontak seksual dengan saudara dekat \\
\hline G031 & Tindakan untuk melakukan kontak seksual dengan saudara dekat \\
\hline G032 & Fantasi untuk berperan sebagai lawan dari jenisnya sendiri \\
\hline G033 & Perasaan jijik terhadap jenis kelaminnya sendiri \\
\hline G034 & Dorongan untuk bertingkah laku seperti lawan jenisnya \\
\hline G035 & Memiliki koleksi pakaian dari lawan jenisnya \\
\hline G036 & Tindakan untuk mengenakan pakaian dan bertingkah laku seperti lawan jenisnya \\
\hline G037 & Menginginkan untuk melakukan pergantian kelamin \\
\hline G038 & Hasrat seksual yang tinggi \\
\hline G039 & Melakukan masturbasi secara berlebihan \\
\hline G040 & Tidak pernah merasa puas dalam melakukan seksualitas \\
\hline G041 & Pernah melihat perilaku seksual binatang \\
\hline G042 & Tertatik secara seksual terhadap binatang \\
\hline G043 & Fantasi seksual terhadap binatang \\
\hline G044 & Kontak seksual dengan binatang \\
\hline G045 & Kepuasan seksual dengan melakukan kontak seksual dengan binatang \\
\hline G046 & Fantasi untuk melakukan kontak seksual dengan laki - laki \\
\hline G047 & Ketertarikan yang berlebihan terhadap laki - laki \\
\hline G048 & Dorongan yang kuat untuk melakukan kontak seksual terhadap laki - laki \\
\hline G049 & Timbul rasa sayang terhadap laki - laki lebih dari sekedar teman, sahabat atau saudara \\
\hline G050 & Timbul rasa cemburu jika laki - laki yang disukai berjalan atau menjalin hubungan dengan lawan jenis \\
\hline G051 & Kontak seksual dengan sesama jenis (laki - laki) \\
\hline G052 & Fantasi untuk melakukan kontak seksual dengan wanita \\
\hline G053 & Ketertarikan yang berlebihan terhadap wanita \\
\hline G054 & Dorongan yang kuat untuk melakukan kontak seksual terhadap wanita \\
\hline G055 & Timbul rasa sayang terhadap wanita lebih dari sekedar teman, sahabat atau saudara \\
\hline G056 & Timbul rasa cemburu jika wanita yang disukai berjalan atau menjalin hubungan dengan lawan jenis \\
\hline G057 & Melakukan kontak seksual dengan wanita \\
\hline
\end{tabular}

Analisa data dilakukan dengan mengklasifikasi beberapa jenis gejala, kemudian digolongkan kepada jenis penyimpangan tertentu. Tabel II menjelaskan macam-acam penyimpangan yang ada.

TABEL II.

TABEL PENYIMPANGAN

\begin{tabular}{cl}
\hline \hline kd_penyimpangan & nama-penyimpangan \\
\hline J001 & Masokisme \\
J002 & Sadisme \\
J003 & Eksibisionisme \\
J004 & Voyeurisme \\
J005 & Pedofilia \\
J006 & Fetishisme \\
J007 & Incest \\
J008 & Transvetitisme \\
J009 & Nimfomania \\
J010 & Zofilia \\
J011 & Homoseksual \\
\hline \hline
\end{tabular}

\section{B. Mesin inferensi}

Dalam proses pelacakan terdapat 12 aturan/role relasi gejala [4] yaitu data aturan relasi gejala dari setiap penyimpangan. Aturan tersebut seperti ditunjukkan pada tabel III. Inputan berupa fakta yang diberikan user adalah data gejala yang dirasakan. Kemudian data-data tersebut disusun kedalam kaidah berbasis aturan, dilanjutkan proses pengecekan apakah kaidah-kaidah tersebut telah sesuai atau tidak, jika tidak maka user akan kembali mengisikan fakta-fakta yang lain. Akan tetapi jika kaidah tersebut sesuai maka kaidah atau fakta tersebut tersimpan dalam file berbasis pengetahuan berupa basis data yang kemudian diproses hingga user bisa melakukan proses konsultasi untuk menghasilkan diagnosa. 
TABEL III.

ATURAN RELASI GEJALA

\begin{tabular}{cll}
\hline \hline kd_penyimpangan & nama-penyimpangan & \multicolumn{1}{c}{ kd-gejala } \\
\hline J001 & Masokisme & G001, G002, G003, G004 \\
J002 & Sadisme & G005, G006, G007 \\
J003 & Eksibisionisme & G008,G009,G010,G011,G012,G013 \\
J004 & Voyeurisme & G014,G015,G016,G017,G018 \\
J005 & Pedofilia & G019,G020,G021 \\
J006 & Fetishisme & G022, G023,G024,G025,G026,027 \\
J007 & Incest & G028,G029,G030,G031 \\
J008 & Transvetitisme & G032,G033,G034,G035,G036,G037 \\
J009 & Nimfomania & G038,G039,G040 \\
J010 & Zofilia & G041,G042,G043,G044,G045 \\
J011 & Homoseksual & G046,G047,G048,G049,G050,G051 \\
J012 & Lesbianisme & G052,G053,G054,G055,G056,G057 \\
\hline \hline
\end{tabular}

Dalam sistem ini metode pelacakan yang digunakan adalah runut maju (forward chaining) karena proses yang dialami dengan menampilakan gejala-gejala menuju konklusi akhir yang berupa nama penyimpangan seksual dan solusi pencegahan sesuai dengan penyimpangan yang dialami. Pelacakan runut maju digambarkan dalam flowchard pada gambar 2 .

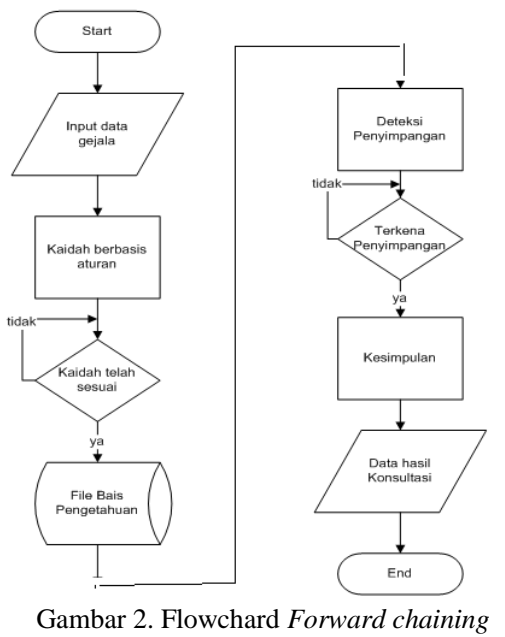

Dalam proses ini pelacakan dimulai dari informasi yang dimasukan yaitu tentang gejala yang (G001, G002, G003, G004) kemudian mencari aturan yang sesuai dengan informasi yang dimasukan (G001, G002, G003, G004). setelah itu mencari fakta yang sesuai dengan basis pengetahuan yang digunakan atau aturan yang digunakan dan selanjutnya mencoba menggambarkan kesimpulan (J001). Hasil kesimpulan aditunagkan dalam laporan hasil konsultasi. Pelacakan ke depan mencari fakta yang sesuai dengan bagian IF dari aturan IF - THEN.

\section{Perancangan Sistem}

Pada diagram Kontek digambarkan sistem berinteraksi dengan dua entitas, yaitu admin dalam sistem juga dapat diwakili oleh psikolog dan masayrakat yang akan berkonsultasi (user) .

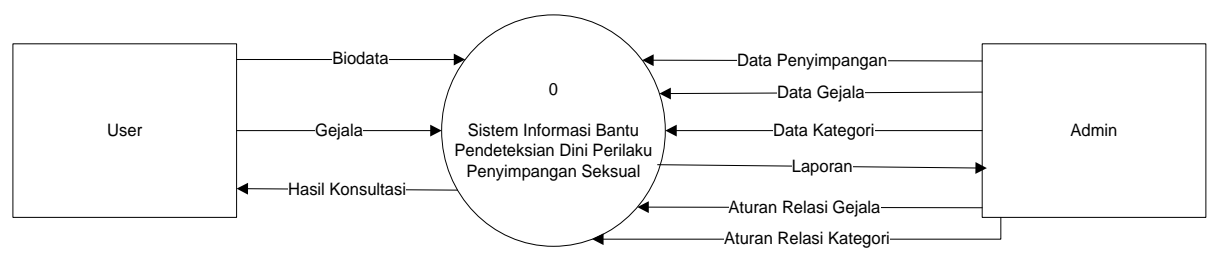

Gambar 3. Diagram konteks sistem deteksi dini perilaku penyimpangan seksual

Entity Relationship Diagram (ERD) untuk deteksi dini perilaku penyimpangan seksual ditunjukkan pada Gambar 4.

D. Implementasi

Proses implementasi atau pengkodean program kedalam bahasa pemrograman. Pengkodean dilakukan dengan php. Berikut adalah hasil implementasi yang dijalankan pada browser Mozilla Firefox 35.0.0 :

Halaman login admin digunakan sebagai layer keamanan data inti dari sistem, ditampilkan pada Gambar 5. 


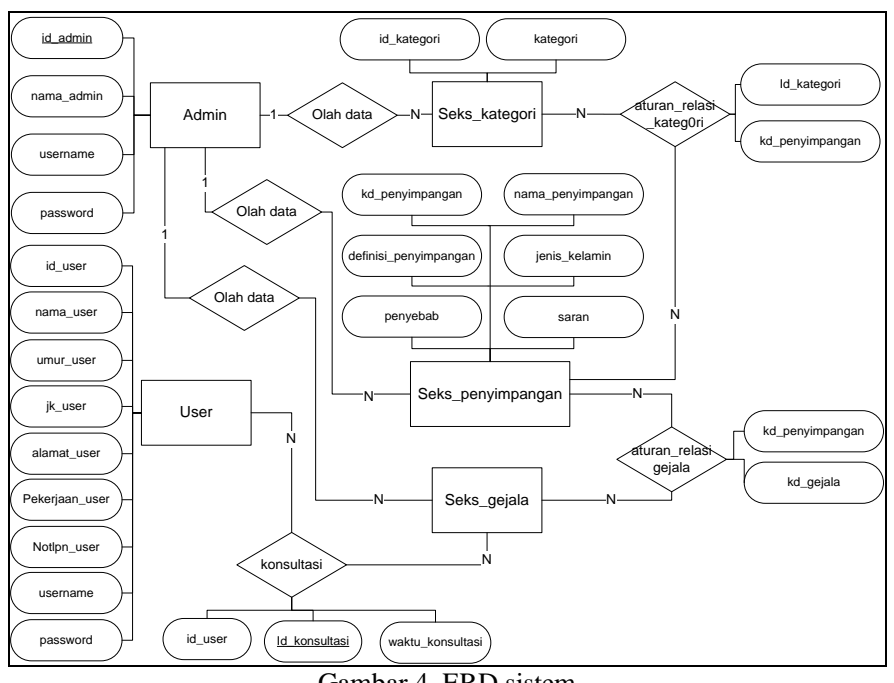

Gambar 4. ERD sistem

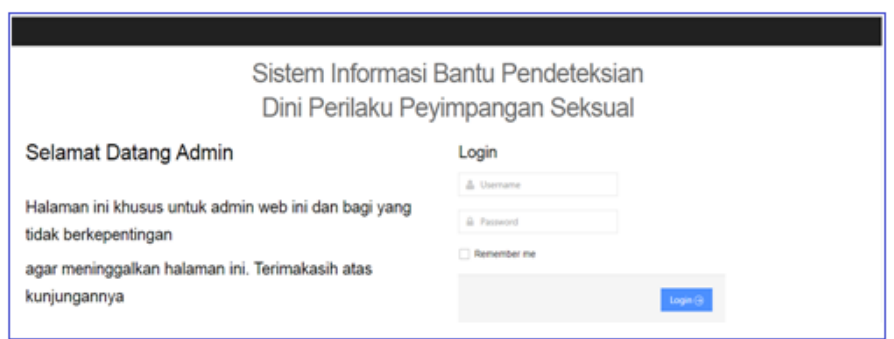

Gambar 5. Halaman Login Admin

Pada halaman konsultasi user akan diberikan daftar gejala berubah checkbox yang dipilih berdasarkan apa yang user rasakan, alami atau user pernah melihat fenomena penyimpangan seksual dengan memilih gejala yang ada. Untuk proses konsultasi lanjut akan ditampilkan daftar gejala yang yang lebih khusus sesuai dengan apa yang di dipilih oleh user. Setelah itu sistem akan memproses berdasar aturan yang ada dan didapatkan kesimpulan penyimpangan yang diderita oleh $u s e r$.

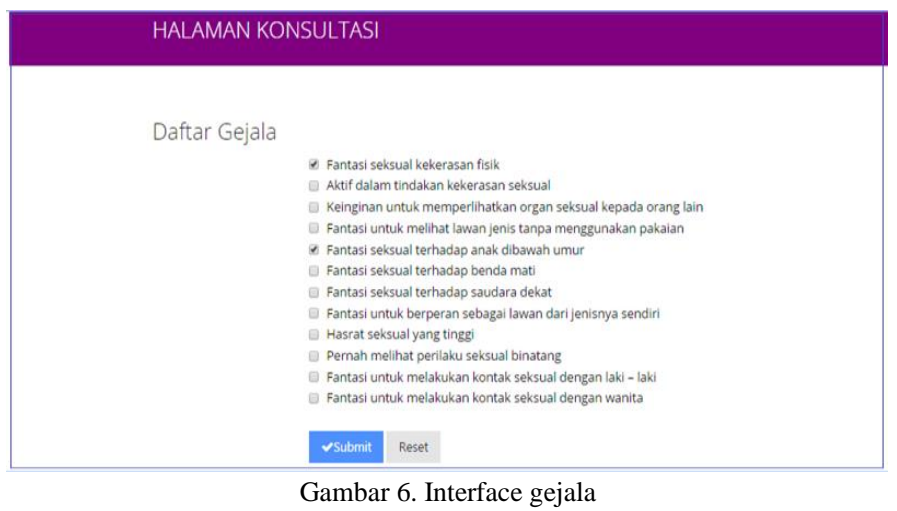

Halaman konsultasi menampilkan daftar gejala yang umum setelah itu di proses oleh sistem, kemudian sistem akan menampilkan halaman konsultasi lanjut dimana daftar gejala yang akan ditampilkan adalah hasil dari proses konsultasi umum ke khusus. Pemilihan gejala khusus dapat dilihat pada gambar 7.

\section{HALAMAN KONSULTASI LANJUT}

\section{Daftar Gejala}

- Seksual disertai tindak kekerasan fisik

- Pasif dalam tindakan kekerasan seksual

- Kepuasan seksual dengan disakiti pasangannya

1 Dorongan yang kuat untuk melakukan kontak seksual dengan anak dibawah umur

- Tindakan untuk melakukan kontak seksual dengan anak dibawah umur

Gambar 7. Halaman Konsultasi Lanjut. 
Setelah itu dianalisis dengan forward chaining oleh sistem untuk menghasilkan informasi tentang kategori penyimpangan seksual untuk user. Listing proses analisis dengan forward chainging dapat dilihat pada gambar 8 .

\begin{tabular}{|c|c|}
\hline No & Script \\
\hline 1 & $<$ ?php \\
\hline 2 & include "koneksi.php"; \\
\hline 3 & \$kd_penyimpangan=\$_POST['kd_penyimpangan'] ; \\
\hline 4 & $\$ s t r O R=1 ' ;$ \\
\hline 5 & \$stron=' '; \\
\hline 6 & for $(\$ i=0 ;$ \$i <izeof (\$kd_penyimpangan); $i++) \quad\{$ \\
\hline 7 & \$nyimpang = substr (\$kd penyimpangan $[\$ i], 0,4) ;$ \\
\hline 8 & \$gejala = substr $(\$ \mathrm{kd}$ penyimpangan $[\$ i], 5) ;$ \\
\hline 9 & \$strOR .=" OR sr.kd penyimpangan='". \$nyimpang."' "; \\
\hline 10 & \$stron .=",'". \$gejala."' "; \\
\hline 11 & \} \\
\hline 12 & \$stron = substr $(\$ s t r o n, 1) ;$ \\
\hline 13 & \$strOR = substr $(\$ s t r O R, 4) ;$ \\
\hline 14 & if $\left(\right.$ \$strOR $\left.!=\prime^{\prime}\right) \quad\{$ \\
\hline 15 & $\begin{array}{l}\text { \$result=mysql_query("SELECT * FROM (SELECT sg.`nm_gejala`, sg.`kd_gejala' } \\
\text { from seks_aturan_relasigejala as sr LEFT JOIN seks_penyimpangan as sp ON } \\
\text { sp.kd_penyimpangan = sr.kd_penyimpangan JOIN seks_gejala as sg ON } \\
\text { sg.kd_gejala = sr.kd_gejala AND (".\$strOR.") GROUP BY sg.kd_gejala)tes } \\
\text { WHEREkd_gejala NOT IN (".\$stron.")"); }\end{array}$ \\
\hline 16 & while (\$data = mysql fetch array (\$result)) \{ \\
\hline 17 & $\begin{array}{l}\text { echo "<label class='checkbox line'><input type='checkbox' } \\
\text { name='kd_gejala[]' value='\$data[kd_gejala] '/>\$data[nm_gejala] </label>"; }\end{array}$ \\
\hline 18 & \} \\
\hline 19 & $\begin{array}{l}\text { \$result=mysql_query("SELECT * FROM seks_gejala WHERE kd_gejala IN } \\
(" . \text { stron.")"); }\end{array}$ \\
\hline 20 & while (\$data = mysql_fetch_array (\$result)) \{ \\
\hline 21 & $\begin{array}{l}\text { echo "<input type='hidden' checked name='kd_gejala[]' } \\
\text { value='\$data[kd_gejala]' />"; }\end{array}$ \\
\hline 22 & $x_{0}=0$ \\
\hline 23 & \} \\
\hline 24 & $?>$ \\
\hline
\end{tabular}

\section{PEMBAHASAN}

Hasil keputusan dari sistem dapat digunakan untuk sebagai acuan konsultasi kepada psikolog. Bentuk laporan yang dihasilkan oleh sisitem terlihat pada Gambar 10.

\section{A. Pengujian Sistem}

Pengujian black box dilakukan untuk mengetahui apakah data dan rule yang dgunakan benar sehingga menghasilkan analisa diagnosa yang akurat. Berdasarkan hasil pengujian, ditarik kesimpulan bahwa kinerja sistem telah menunjukkan adanya kesesuaian antara masukan dan output hasil diagnosa sehingga hasil analisa sistem Deteksi Dini Perilaku Penyimpangan Seksual layak digunakan. Pengujian Alpha Test dilakukan untuk mengetahui apakah sistem dapat digunakan secara mudah dan memberikan informasi yang cukup jelas untuk calon pengguna. Hasil pengujian tersebut dapt diketahui bahwa sistem telah berjalan dengan baik dan berfungsi sebagaimana mestinya. Persentase hasil yang menyatakan Sangat Setuju adalah 47\% dan Setuju adalah 53\%, maka dapat disimpulkan bahwa Sistem layak untuk diimplementasikan ke masayarakat.

Hasil vaidasi secara alfa test dapat dilihat pada grafik hasil uji pada Gambar 9.

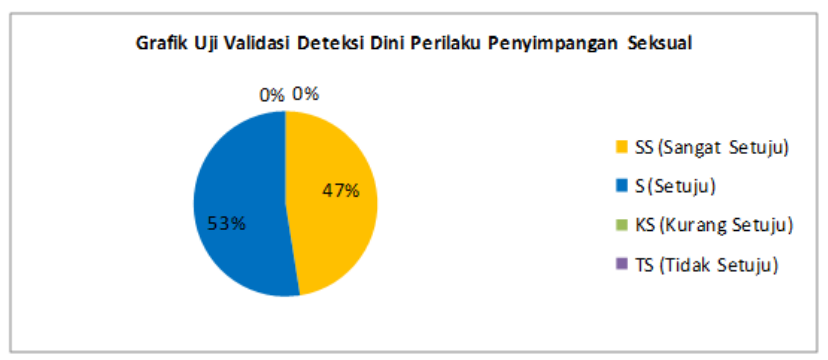

Gambar 9. Diagram hasil kuisioner dengan alfha test.

\section{SIMPULAN DAN SARAN}

Sistem deteksi Dini Perilaku Penyimpangan Seksual dengan menggunakan metode Forward Chaining berbasis Web dapat digunakan sebagai media informasi untuk mendeteksi secara mandiri jenis penyimpangan seksual melalui gejala yang dialami. Deteksi Dini Perilaku Penyimpangan Seksual Menggunakan Metode Forward Chaining Berbasis Web yang telah diuji dan dapat digunakan. Hal ini dibuktikan dengan hasil kuisioner pengujian 
black box test dengan hasil 100\% sesuai dan persentasi hasil pengujian alpha test menyatakan Sangat Setuju adalah $47,5 \%$ dan Setuju adalah 52,5\%.

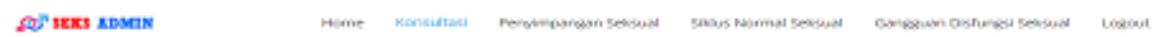

\section{KONSULTASI}
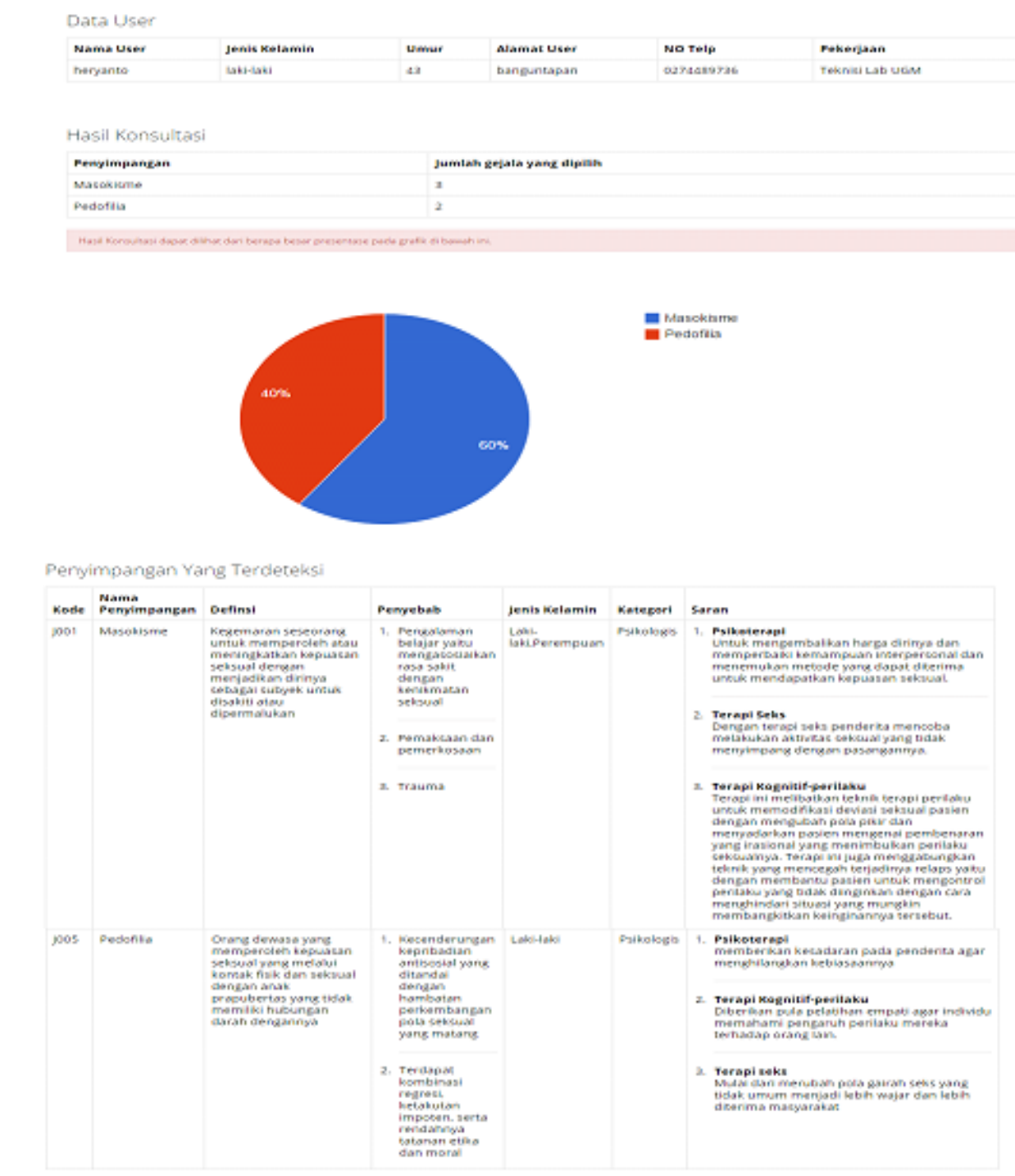

Enasckim

Gambar 10. Halaman Hasil Konsultasi

\section{REFERENSI}

[1] Davision, C,. Gerald., Neale, M., john, Kring, M., Neale, Psikologi Abnormal, Rajawali Pers, Jakarta; 2006

[2] Durkin, John. 1994. Expert Systems Design and Development. New Jersey: Prentice Hall.

[3] Russel S, Norvig P, Artificial Intelligence A Modern Approach, the third edition, ISBN : 0-13-604259-7, December 2009.

[4] Fausiah,F. \&Widury, JPsikologi Abnormal Klinis Dewasa. Jakarta: Penerbit Universitas Indonesia; 2008.

[5] Kusrini, Aplikasi Sistem Pakar, Menentukan Faktor Kepastian Pengguna Dengan Metode Kuantifikasi Pertanyaan. Yogyakarta : Andi; 2009. 